\title{
Factors Affecting Adherence to Treatment of Inpatients with Alcohol Addiction: a Qualitative Study
}

\author{
Emel Bahadir Yilmaz ${ }^{1}\left(\mathbb{D}\right.$, Elvan E. Ata ${ }^{2}$ (D) \\ ${ }^{1}$ Giresun University, Department of Psychiatric Nursing, Giresun, Turkey. \\ ${ }^{2}$ University of Health Sciences, Hamidiye Nursing Faculty, Department of Psychiatric Nursing, İstanbul \\ Correspondence Author: Emel Bahadir Yilmaz \\ E-mail: ebahadiryilmaz@yahoo.com, emel.bahadir.yilmaz@giresun.edu.tr \\ Received: $30.11 .2020 \quad$ Accepted: 06.08.2021
}

\begin{abstract}
Objective: This paper explores those factors affecting adherence to treatment among inpatients with alcohol addiction in Turkey.

Methods: This qualitative and descriptive study was carried out in 2018. The sample consisted of 16 patients with alcohol addiction in a psychiatric clinic. The data were analyzed using content analysis.

Results: Three main themes emerged from these interviews: (1) strengthening of personality; (2) structuring of treatment environment; and (3) completion of social life preparations. Strengthening of personality theme was composed of low self-esteem, anger and ineffective coping, inadequate communication skills, and loneliness sub-themes. Structuring of treatment environment theme consisted of lack of knowledge and insight, a non-therapeutic environment, and lack of treatment motivation sub-themes. Finally, completion of social life preparations theme was composed of lack of leisure activity, fighting the stigma of alcoholism, failure to initiate change and insufficient social support sub-themes.

Conclusion: This study suggests that psychiatric nurses should improve patients' self-esteem, coping and communication skills, and increase patients' knowledge and insight about their disorder and medication, treatment motivation, and social support resources.
\end{abstract}

Keywords: alcohol addiction, adherence to treatment, qualitative study, nursing

\section{INTRODUCTION}

Alcohol addiction causes many physical and mental health problems. As a psychiatric disorder, alcohol addiction can result in deterioration in the continuity of family processes, economic problems, and impaired occupational abilities (1-3). Some research has reported that alcohol addiction originates from psychosocial problems causes many psychosocial problems, such as separation/divorce, dismissal, and problems and encounters with the police (4). Despite these problems, alcohol addicts fail to accept their illnesses and to maintain regular treatment (5).

Approximately $10 \%$ of women and $20 \%$ of men meet the criteria for alcohol abuse throughout their lives, and $3-5 \%$ of women and $10 \%$ of men are diagnosed with alcohol addiction. The age group in which active alcohol use is most common is the 20-35 age group (4). Existing studies in the field have determined that the majority of alcohol addicts have low levels of education, low course success, and middle or low levels of income; furthermore these researches have shown alcohol addiction to be higher in males, and unemployed and unmarried individuals $(4,6)$. These factors may also impair individual patients' adherence to treatment. Adherence to treatment, which plays an important role in the treatment of individuals with serious mental health problems such as alcohol addiction, is influenced by the patient's social support resources, such as their family and friends, and the attitudes of health workers responsible for providing their care $(7,8)$.

Adherence to treatment is considered to be an important component in the patient's psychiatric treatment regarding their adoption of a treatment program, regular use of medicines as prescribed or recommended by their doctor, and changes to their way of life $(7,9,10)$. In order to increase patients' adherence to treatment, regular implementation of certain practices, such as strengthening coping skills, mobilizing support systems, creating an environment that makes it easier for the individual patient to express their feelings and thoughts, and developing patients' problemsolving skills, must be regularly implemented (3). The literature also states that patients' intrinsic motivation, and their motivation for interpersonal help seeking and treatment is increased by providing a treatment environment 
that enables addictive patients to understand their own feelings and personal problems and to increase their courage to talk with health personnel about themselves and their past (11). In this respect, it is important to configure those clinics in which patients are treated in a therapeutic manner. Therapeutic environments increase the patient's compliance with the medication, which makes it easier for them to cope with problems they encounter in their social life after they have been discharged. Accordingly, the aim of the current study is to determine those factors affecting adherence to treatment among inpatients with alcohol addiction.

\section{METHODS}

\subsection{Participants}

This qualitative and descriptive study was conducted in a psychiatry service in northeastern Turkey. This study was reported using the consolidated criteria for reporting qualitative studies (12). The study, which used a purposive sampling method, aimed to explore the factors affecting adherence to treatment among male inpatients with alcohol addiction. Overall, 16 patients were recruited; all these patients met the study's inclusion criteria and were hospitalized in service between 1 January and 31 June 2018. Since only male patients received treatment at the clinic during the study, they were included in the sample. This study was conducted in a 23-bed, adult psychiatric clinic in Giresun University Training and Research Hospital. Five nurses who are high school graduates and seven doctors work in the clinic. At the time of the study, there were no therapeutic studies in the clinic; patients only received drug therapy.

The inclusion criteria were as follows: to be 18-65 years old, to be diagnosed with alcohol addiction and volunteering to participate in the research. The exclusion criteria required that patients had problems related to: hearing or understanding, memory problems, or withdrawal syndrome or patients had other mental illnesses including anxiety disorders and personality disorders. Accordingly, three patients with anxiety disorder, one patient with bipolar disorder, and one patient with memory problems, were excluded from the study. Background data for the 16 patients with alcohol addiction used in this study can be seen in Table 1.

\subsection{Instruments}

A "demographic information form" and "semistructured interview form" were used to collect the study data.

2.2.1. Demographic information form: This form comprised questions aimed at identifying the age, educational level, employment status, marital status, and number of children of the study participants.
Table 1. Background Data for 16 Patients with Alcohol Addiction Used in the Current Study

\begin{tabular}{|c|c|c|c|c|c|c|}
\hline Patients & Age & $\begin{array}{l}\text { Marital } \\
\text { status }\end{array}$ & $\begin{array}{c}\text { Educational } \\
\text { level }\end{array}$ & $\begin{array}{c}\text { Number } \\
\text { of } \\
\text { children }\end{array}$ & $\begin{array}{l}\text { Working } \\
\text { status }\end{array}$ & $\begin{array}{c}\text { Number of } \\
\text { hospitalizations }\end{array}$ \\
\hline $\begin{array}{c}\text { Patient } \\
1\end{array}$ & 42 & married & $\begin{array}{l}\text { primary } \\
\text { school }\end{array}$ & 3 & working & 2nd \\
\hline $\begin{array}{c}\text { Patient } \\
2\end{array}$ & 41 & married & high school & 1 & working & $1 s t$ \\
\hline $\begin{array}{c}\text { Patient } \\
3\end{array}$ & 52 & single & high school & 3 & retired & $1 \mathrm{st}$ \\
\hline $\begin{array}{c}\text { Patient } \\
4\end{array}$ & 41 & single & $\begin{array}{l}\text { primary } \\
\text { school }\end{array}$ & - & $\begin{array}{c}\text { not } \\
\text { working }\end{array}$ & 4th \\
\hline $\begin{array}{c}\text { Patient } \\
5\end{array}$ & 44 & single & high school & 2 & working & 2nd \\
\hline $\begin{array}{c}\text { Patient } \\
6\end{array}$ & 57 & single & university & 2 & retired & 5 th \\
\hline $\begin{array}{c}\text { Patient } \\
7\end{array}$ & 38 & single & $\begin{array}{l}\text { primary } \\
\text { school }\end{array}$ & 2 & $\begin{array}{c}\text { not } \\
\text { working }\end{array}$ & 2nd \\
\hline $\begin{array}{c}\text { Patient } \\
8\end{array}$ & 35 & married & high school & 1 & working & 2nd \\
\hline $\begin{array}{c}\text { Patient } \\
9\end{array}$ & 43 & single & $\begin{array}{l}\text { primary } \\
\text { school }\end{array}$ & 2 & $\begin{array}{c}\text { not } \\
\text { working }\end{array}$ & $1 s t$ \\
\hline $\begin{array}{c}\text { Patient } \\
10\end{array}$ & 43 & single & $\begin{array}{l}\text { secondary } \\
\text { school }\end{array}$ & 1 & working & $3 r d$ \\
\hline $\begin{array}{c}\text { Patient } \\
11\end{array}$ & 63 & married & $\begin{array}{c}\text { primary } \\
\text { school }\end{array}$ & 3 & working & $3 r d$ \\
\hline $\begin{array}{c}\text { Patient } \\
12\end{array}$ & 59 & single & $\begin{array}{l}\text { primary } \\
\text { school }\end{array}$ & 1 & working & $1 s t$ \\
\hline $\begin{array}{c}\text { Patient } \\
13\end{array}$ & 57 & single & $\begin{array}{l}\text { primary } \\
\text { school }\end{array}$ & 3 & $\begin{array}{c}\text { not } \\
\text { working }\end{array}$ & 2nd \\
\hline $\begin{array}{c}\text { Patient } \\
14\end{array}$ & 45 & married & $\begin{array}{c}\text { primary } \\
\text { school }\end{array}$ & 3 & working & 1st \\
\hline $\begin{array}{c}\text { Patient } \\
15\end{array}$ & 61 & single & $\begin{array}{c}\text { primary } \\
\text { school }\end{array}$ & 3 & retired & 2nd \\
\hline $\begin{array}{c}\text { Patient } \\
16\end{array}$ & 49 & married & $\begin{array}{l}\text { primary } \\
\text { school }\end{array}$ & 6 & $\begin{array}{c}\text { not } \\
\text { working }\end{array}$ & $3 r d$ \\
\hline
\end{tabular}

2.2.2. Semistructured interview form: This form covered semistructured questions prepared for the interviews with male inpatients with alcohol addiction. All interviews were carried out based on previous hospitalization experiences, personality characteristics, familial and social support systems, current treatment processes about hospitalization, characteristics of psychiatric service, leisure time activities, and future plans. A pilot study was conducted with three patients. Questions were understandable. There was no problem when the patients answered the questions. Therefore, the questions were not changed. Questions are as follow: (1) Have you ever been treated for alcohol addiction? If you did, were you able to adherence to the treatment? What were the factors that decreased or increased your adherence to the treatment? (2) Are you able to adherence to the treatment you are currently receiving? What are the factors that decrease or increase your adherence to the treatment? (3) How does your family affect you in this process? Can you get support from them? How does this process affect your family? (4) How do your friends assess your hospitalization for treatment? Do they support you? 
(5) How do you evaluate the environment in which you are being treated? How does it affect your treatment process? How is your communication with healthcare professionals? (6) How does alcohol use affect your work-life positively / negatively? (7) Have you ever tried to quit alcohol? What are your experiences? (8) What do you intend to change in your life after leaving here?

\subsection{Data Collection}

The individual interviews were conducted with the patients in the interview room by using "in-depth interviews method". The patients were informed about the study, and consent was obtained from each voluntary participant. Each interview lasted approximately 45-60 minutes and was audio recorded. The repeated interviews were not conducted with the same patient. The data collection was continued until data saturation had been reached in each interview. First researcher has a qualitative research certificate and conducted the interview. The researchers have a doctorate degree in psychiatric nursing, are female, and work as lecturer during the study. There was no relationship between the patients participating in the study and the researchers before the study. At the time of the study, the researchers had no clinical affiliation. Prior to the research, the first researcher introduced herself and informed the participants about the aims of the research and how it would be conducted.

\subsection{Data Analysis}

Interviews were transcribed verbatim and interpreted so as to determine themes using the conceptual framework developed by Graneheim and Lundman (13): (1) First, answers given by participants were read through by both authors repeatedly before being subjected to a content analysis. Both authors met several times to reflect upon and discuss their analysis until they reached an agreement about the findings. (2) The meaningful textual units were identified from among the participants' answers. (3) The meaning units were abstracted and labelled with codes. (4) Codes were interpreted and 11 sub-themes were created. (5) Lastly, 3 main themes were determined. The themes, sub-themes, and codes were read by the participants.

\subsection{Rigor of the Findings}

In this study, the principles of credibility, transferability, consistency, and confirmability were used to ensure validity and reliability (14). The transcriptions of participant responses were read through several times so as to obtain a sense of the whole. To ensure the credibility of the data, the themes and sub-themes were not approve by the patients, but expert opinion had been taken.

\subsection{Ethical Consideration}

This study was approved by the ethics committee of Medical Sciences of Giresun University ( date: 20.12.2017, number:
09/01) and conducted according to the ethics guidelines set out in the Declaration of Helsinki. Verbal and written consent was obtained from all participants. All participants were informed about the purpose and design of this research and were guaranteed anonymity and confidentiality throughout the study.

\section{RESULTS}

Three main themes were obtained as a result of the study analyses: strengthening of personality, structuring of treatment environment, and completion of social life preparations.

\subsection{Theme 1: Strengthening of Personality}

\subsubsection{Low self-esteem}

It was determined that patients who were unable to live individually and without support felt excluded, experienced broken relationships with their family, and experienced negative feelings such as guilt and shame, while also believing themselves to be relatively worthless and hopeless.

I feel strong willed and good when I drink. (P4)

I don't expect anything from the future. I lived as long as I lived. The rest is not very important. Life has little meaning for me. (P13)

I'm a person who is shy and who cares about what people think. (P15)

\subsubsection{Anger and ineffective coping}

Most of the patients with alcohol addiction defined that they were nervous and had problems in managing their anger.

I'm a little nervous. I'm an emotional person. I can't control myself during a discussion. (P8)

I get very angry. I'm so afraid of hurting someone else when I'm angry. Then I am regretful. (P6)

Patients described many sources of stress relating to their family, work, and social lives, and reported that they used alcohol to cope with these stressors.

I started to use alcohol more to deal with work stress. (P3)

When I was 13 , I learned that I had been adopted. I'm very angry with my family. (P5)

Some patients stated that they sometimes directed their anger to themselves or another person.

When I drink, I feel no harm toward someone else, I have more self-harm. I cut my arm with a knife. (P1)

When I get angry, I cry, I yell. I don't hurt anybody else, but I'm hurting myself. I've attempted suicide three times before. In the first instance, I drank drugs. The second time, I cut my wrists. Third, I jumped off a bridge. (P4) 


\subsubsection{Inadequate communication skills}

Patients stated that they had problems expressing their feelings and thoughts, saying no, and asking for help in solving their problems.

After my first admission, one day my friends arrived after I was discharged. They offered me a glass of a drink while they were drinking and chatting. I didn't break them. I don't want to break anybody. I can't say no to people not to hurt them. (P15)

I don't tell anyone about my problem, and can't share my problems. I always try to handle it myself. (P2)

Patients who could not express themselves, and therefore could not communicate with other people, stated that they felt alienated from their environment and felt alone.

For me, drinking is a habit, my best friend. I cannot communicate with people for a long time as personality, I get bored, my soul is shrinking. (P3)

I live in a small environment and I feel alienated from the environment. I get bored in crowded environments. (P6)

\subsubsection{Loneliness}

Most patients stated that they felt alone, even if there were people around them; they felt lonely and when they were alone, they wished to drink more alcohol.

I usually spend time alone and drink alone. I came back to my hometown 10 years ago and I couldn't find the environment that I wanted. (P11)

I feel alone. I'd feel better if I had a friend or a spouse in my life. (P5)

I'm alone in the village, and I'm alone here. I don't have a friend with whom to share my feelings and thoughts. (P9)

\subsection{Theme 2: Structuring of Treatment Environment}

\subsubsection{Lack of knowledge and insight}

The patients stated that they read many side effects of drugs in the package insert, they did not want to use their drugs due to side effects, and they stopped using their drugs without consulting a doctor.

I've been on medication before, but I haven't been able to use the medication all the time. The drugs made me fall asleep. This situation affected my business life. I stopped using the drugs to keep my job. (P2)

The side effects of the drugs I used scared me. That's why I stopped using them. I thought it would be better if I didn't. I read about many side effects of the drugs in the package insert. (P8)

Patients reported that they had symptoms related to alcohol withdrawal syndrome such as insomnia, hand and foot tremors, fever, and palpitations when they abstained from drinking alcohol. Participants also reported that they not know how to cope with these conditions or who to ask for when managing them that they continued to drink alcohol again due to ineffective symptom management.

When I get a drink, my work efficiency is increases, the work stress decreases. My hands shake when I don't drink. I can't do my job. (P13)

I have a sleep problem when I don't drink. I'm experiencing hallucinations. (P16)

\subsubsection{Non-therapeutic environment}

The most important factor regarding the disruption of the therapeutic environment for alcohol addicts was shown to be patients with different mental illnesses, who were nevertheless being treated using the same service:

All of the patients with different psychological problems were in the same service. Some patients are calling out and yelling, some patients were lashing out. This situation affects me negatively. (P2)

I think it's not right for all patients to stay in the same service. Some patients have unstable movements. I get scared when I think they can hurt me. (P11)

Another issue expressed by patients in relation to their therapeutic environment concerns the absence of any activity, occupation, individual interviews, or group activities with which to spend their time in the service.

I'm lying here empty. I can't find anything to do. Nobody talks to me here. The interviews, while I was previously hospitalized, helped me a lot. Everyone was talking about their problems in group meetings. (P4)

I'm always watching television, having tea, or drinking coffee. There is nothing to do. (P7)

Some patients also stated that they had difficulties in meeting the self-care needs and service was inadequate in terms of cleanliness / hygiene.

I think this place is neglected. I think such a service should appeal to the eye and the environment should be full of flowers. I think it should be cleaner. (P3)

There are deficiencies in care. Nobody helps me meet my cleaning needs. (P4)

\subsubsection{Lack of treatment motivation}

Most patients reported that they sought out their treatment according to their own wishes, but that they did not decide to quit alcohol; these patients applied to hospital because of the wishes of their families or colleagues, or because of health problems. Patients reported that they were unable to exercise their own will and therefore were unable to abstain from alcohol. 
I'm saying I won't drink when I'm coming here, but I can't stop it. In the evening, I think how I'm gonna sleep without drinking. (P13)

I haven't decided to quit alcohol yet. If I decide one day, I can. My people around me now want me to leave, but I don't want what's important. I can stop drinking if I want. I don't drink in Ramadan. (P9)

\subsection{Theme 3: Completion of Social Life Preparations}

\subsubsection{Lack of leisure activity}

On the one hand, some patients stated that they could not find anything to do in their leisure time. On the other hand, the patients who evaluated their leisure time reported that they did not feel the desire to drink, or that cravings for alcohol had decreased during leisure time.

In my leisure time, if I do something, if I do not empty my day I do not have the opportunity to drink. (P5)

In my leisure time, I sit in the barbershop and drink tea and coffee until the evening. I'm on the phone. I'm not doing anything else. (P7)

\subsubsection{Fighting the stigma of alcoholism}

Patients reported that people in their neighborhood and their friends mocked them for both their disease and hospitalization; accordingly, they did not want to tell anyone they were hospitalized. There were even patients who did not tell their family when they were admitted into the clinic.

I think a lot about the negative things the environment says about drinking alcohol. My friends' environment is not very supportive about it. They said you were crazy when they heard I was hospitalized here. (P1)

People at work and around me don't know I'm in the hospital. My wife does not want it to be known. (P2)

I didn't tell my friends and children that I was hospitalized here. (P9)

\subsubsection{Failure to initiate change}

Most patients stated that they started using alcohol because of their friends. In fact, patients who had previously experienced alcohol withdrawal also reported that they started to use alcohol again because of their friends. However, when patients' future plans were evaluated, some stated that they did not want to change their lives or that it was impossible to make such changes.

I was stubborn with a friend because of drinking. Then I started drinking. (P7)

I don't want to change anything in my life after I'm discharged from here. (P6)

I will continue my life in the same way after I'm discharged from here. (P11)

\subsubsection{Insufficient social support}

During their treatment for addiction, many patients stated that their families and friends did not support their treatment efforts, and that they mostly consumed alcohol with their friends. Patients reported that their families did not believe that the treatment interventions could fail, and therefore did not support treatment interventions.

My friends were not very supportive about it. They said you were crazy when they heard I was hospitalized here. I don't think I'll see any support from them. (P14)

My wife didn't want me to go to the hospital. She said that you're going to start drinking again. (P5)

My friends don't want me to leave the alcohol. They say you start to drink again tomorrow. (P13)

\section{DISCUSSION}

The present study found that patients with alcohol addiction also had certain personality characteristics, including: low self-esteem, anger and ineffective coping, ineffective communication skills, and loneliness. In a study by Engin and Savaşan (5) exploring factors affecting the psychotherapy process of alcohol dependents, it was found that suppressed anger scores and internal-external locus of control scores were associated with discontinued treatment among patients. A further study by Ekinci et al. (15) found that, as patients' level of anger increased, the impact of the substance used on the patients' life and the patients' cravings for that substance increased. Mitrovic et al. (16) stated that patients with alcohol addiction were characterized by low self-esteem, higher levels of tension, anxiety, sensitivity to criticism, insecurity and indecisiveness. According to Çam and Ayakdaş-Dağlı (17), patients who have negative emotions, such as guilt and shame, tend to drink alcohol as a way of coping with these emotions. This vicious circle adversely affects the treatment of patients and increases the possibility of relapse (18). Due to increasing treatment motivation, patients should be educated and empowered about managing their anger and improving their self-esteem.

Similar to the present study, a study by Bokhan et al. (19) determined that maladaptive strategies, such as denial, dissimulation, and dissociation, were generally used by alcohol addicts. Stressful life events and ineffective coping strategies were found to play a considerable role in patients' relapsing (20). Furthermore, alcohol addicts with familial problems, such as a failed marriage or conflicts with their children, were found to experience emotional guilt and shame which led to a withdrawal from social relations (21). Research has also found that such patients are aggressive and violent toward their wives and children, leading to conflicts, and frequent arguments which can result in disturbed communication, such as silence, blame, complaints, and guilt (22). Patients with ineffective means of coping strategies and ineffective communication skills can fail to adhere to 
treatment. For these reasons, their coping strategies and communication skills must be improved.

The present study determined that the following factors were associated with structuring the treatment environment: lack of knowledge and insight, non-therapeutic environment, and lack of treatment motivation. Patient-nurse interaction is an important component of a patients' therapeutic environment. According to one study by Thurang et al. (23), alcohol addicts defined being connected to professional caregivers as being with a person with whom they felt safe, and that they believed to be secure and confident. Being connected to professional caregivers can increase patients' treatment motivation. A study by Evren et al. (24), determined that treatment motivation and outpatient clinic control, and attendance at an outpatient treatment program, all reduced in a relapsed group of patients compared with a non-relapsed group. A further research study also found that the therapeutic service environment aimed at increasing autonomy, spontaneity, program clarity, confidence in treatment, and personal problem orientation for patients increased patients' motivation for treatment (11). Occupational therapy, sport activities, individual or group therapies are all components of the therapeutic environment. Greater use of individual sessions with relevant health professionals was associated with better quality of life and lower levels of depression, as predictors of patients' adherence to treatment (25). In summary, among patients who did not adhere to treatment it was found that hospitalization, morbidity and mortality increased, occupational and familial problems arose, and the patient's quality of life decreased (26).

Lastly, the present study uncovered several factors associated with the completion of social life preparations: lack of leisure activity, fighting the stigma, failure to initiate change, and insufficient social support. As a barrier disrupting patients' adherence to treatment for alcohol addiction, it was found that changing risky environment increases craving (24). Greater motivation for changing and efforts to control craving decreases alcohol use and craving (27) and, therefore, it is important that patients receive assistance from nurses when changing their environmental contingencies to establish a lifestyle that is more rewarding than their current lifestyle which is centred on or reliant on drinking (28). To initiate changes in their lives, patients need social-support resources. Accordingly, patients experiencing insufficient social support from their family, friends, or health professionals are more likely to experience loneliness (29). Insufficient social support and loneliness increased the risk of suicide among alcohol addicts $(30,31)$. Psychosocial interventions in a therapeutic environment should be planned by nurses so as to enable patients to more effectively initiate change in their lives.

Leisure activities are important if patients are to make successful changes to their lives, conduct activities that lead to a sense of freedom, and experience satisfaction, and successful management and balance of their life needs and activities (32). The problems associated with decreased involvement in social, family and professional activities due to alcohol use result and cause recurrent alcohol consumption, and a deficient role in social and family integration among alcohol patients (33). Furthermore, family and social relations that break down due to alcohol use can lead to social isolation and internalized stigma. In light of these findings within the present study, stigma can be said to be a factor that disrupts patients' adherence to treatment. The perception of stigma as experienced by alcoholism results from internalized stigmatization, which itself stems from cognitive and affective internalization of the patients' actual stigmatization by society at large. Being stigmatized by others results in the experience of negative emotions, such as guilt, shame, feelings of inferiority, deterioration in family and friendship relationships among patients with alcoholism (17). According to Yıldırım et al. (34), internalized stigma among patients with alcohol addiction also results on negative effects such as social isolation, low self-esteem, a sense of exclusion, depression, and negative adherence to treatment in patients.

This study has some limitations. Firstly, the findings of the study cannot be generalized to all patients with alcohol addiction. Secondly, the study sample consisted of a small group. Thirdly, only male alcohol addicts were found in the study. Finally, the data were collected in the hospital environment during the treatment process. This situation may have affected the patients' responses. But treatment of alcohol addiction is a long process. This study has provided valuable findings to the literature in terms of determining the factors affecting adherence to treatment of male inpatients with alcohol addiction.

\section{CONCLUSION}

The results of the current study show that certain factors, such as strengthening of personality, structuring of treatment environment, and the completion of preparations concerning the patient's social life are important components of treatment for patients with alcohol addiction. Male inpatients with alcohol addiction have low self-esteem, feelings of anger and loneliness, ineffective coping, and inadequate communication skills. The psychiatric clinic has a non-therapeutic environment. Health care professionals in psychiatric clinic are lack of knowledge and insight about alcohol addiction. Male inpatients with alcohol addiction have some social life problems, such as lack of leisure activity, the stigma of alcoholism, failure to initiate change and insufficient social support.

\subsection{Relevance for Clinical Practice}

Interventions such as individual and group therapies that improve self-esteem, coping and communication skills, increase knowledge and insight about the patients' disorder and medication, treatment motivation and social support resources should be planned and implemented by nurses and other clinicians. Nurses and other healthcare professionals in psychiatric clinics should create a therapeutic environment 
for patients. They should improve patients' self-expression, communication and social skills using therapeutic communication techniques. In the struggle against stigmatization, it is important to mobilize social support systems of patients with alcohol addiction. It is important for professionals working in psychiatry clinics to graduate from undergraduate and graduate programs in terms of providing a professional approach to solving problems. High school graduate nurses will not be sufficient to create a therapeutic environment.

Support: no sources of any supports

Conflict of interest: The authors report no actual or potential conflict of interest.

\section{Acknowledgements}

This study is accepted as an oral presentation at the 3rd Symposium of Family-Based Approach in Nursing, Giresun, Turkey, May 3, 2019. The authors would like to thank all study participants for participating in the study.

\section{REFERENCES}

[1] Uluğ $B$, Öztürk O. Psikoaktif madde kullanimina bağli ruhsal bozukluklar. In: Öztürk $M$, Uluşahin $A$, eds. Ruh Sağlığı ve Bozuklukları 14th ed. Ankara: Nobel Tip Kitabevi; 2016. p. 511554. (Turkish)

[2] Çam O, Engin E (Editors). Madde bağımlılığı. Ruh Sağlığı ve Hastalıkları Hemşireliği: Bakım Sanatı. 1st ed. İstanbul: İstanbul Medikal Yayıncılık; 2014. p. 447-484. (Turkish)

[3] Fırıncık S. Madde ve bağimlilik. In: Gürhan N, ed. Ruh Sağliği ve Psikiyatri Hemşireliği. Ankara: Nobel Tıp Kitabevi; 2016. p. 621-662. (Turkish)

[4] Ince A, Doğruer Z, Türkçapar MH. Erken ve geç başlangıçlı erkek alkol bağımlılarında sosyodemografik, klinik ve psikopatolojik özelliklerin karşılaştırılması. Klinik Psikiyatri 2002;5:82-91. (Turkish)

[5] Engin E, Savaşan A. Investigation of factors affecting the process of psychotherapy of alcohol dependents. Journal of Psychiatric Nursing 2012;3(2):75-79.

[6] Türkmen SN, Kumaşoğlu Ç, Akyol T. Alkol ve madde bağımlılığı tedavi ve eğitim merkezi (AMATEM) biriminde yatan bireylerde içselleştirilmiş damgalanma ve yaşam kalitesi. Journal of Dependence 2015;16(4):182-191. (Turkish)

[7] Kelleci M, Ata EE. Psikiyatri kliniğinde yatan hastaların ilaç uyumları ve sosyal destekle ilişkisi. Journal of Psychiatric Nursing 2011;2(3):105-110. (Turkish)

[8] Aylaz R, Kılınç G. The relationship between treatment adherence and social support in psychiatric patients in the east of Turkey. Arch Psychiatr Nurs. 2017;31(2):157-163.

[9] Koeter MWJ, van den Brink W, Lehert P. Effect of early and late compliance on the effectiveness of acamprosate in the treatment of alcohol dependence. J Subst Abuse Treat. 2010;39(2):218-26.

[10] Velligan DI, Weiden PJ, Sajatovic M, Scott J, Carpenter D, Ross $R$, Docherty JP. Assessment of adherence problems in patients with serious and persistent mental illness: recommendations from the expert consensus guidelines. J Psychiatr Pract. 2010;16(1):34-45.
[11] Savaşan A. Bağımlılığı olan hastalarda servis ortamı ve tedavi motivasyonu ilişkisinin incelenmesi. Klinik Psikiyatri 2010;13:119-126. (Turkish)

[12] Tong A, Sainsbury P, Craig J. Consolidated criteria for reporting qualitative research (COREQ): a 32-item checklist for interviews and focus groups. Int J Qual Health Care. 2007;19(6):349-357.

[13] Graneheim UH, Lundman B. Qualitative content analysis in nursing research: concepts, procedures and measures to achieve trustworthiness. Nurs Educ Today. 2004;24(2):105-112.

[14] Holloway I, Wheeler S. Qualitative Research in Nursing and Healthcare. 3rd ed. Oxford: Wiley-Blackwell; 2013

[15] EkinciS, Kural HU, Yalçınay M. Madde bağımlılığı olan hastalarda öfke düzeyi, bağımlılık profili, depresyon ve anksiyete düzeyi ile ilişkisi. Journal of Dependence 2016;17(1):12-17. (Turkish)

[16] Mitrovic M, Hadzi-Pesic M, Stojanovic D, \& Milicevic N. Personality traits and global self-esteem of alcohol addicts. Procedia Soc Behav Sci. 2014;127:255-259.

[17] Çam O, Ayakdaş-Dağlı D. Alkol bağımlılarında içselleştirilmiş damgalama, suçluluk ve utanç duyguları. Journal of Dependence 2017;18(4):145-151. (Turkish)

[18] Baysan-Arabacı L, Ayakdaş-Dağı D, Taş G. Madde kullanım bozukluklarında duygu düzenleme güçlüğü ve hemşirelerin rol ve sorumlulukları. Journal of Dependence 2018;19(1):10-16.

[19] Bokhan NA, Mandel AI, Stoyanova IY, Mazurova LV, Aslanbekova NV, Ankudinova IE. Psychological defense and strategies of coping in alcohol dependence and co-dependence in women. Journal of Psychology \& Psychotherapy 2013;3(5):128.

[20] Hassanbeigi A, Askari J, Hassanbeigi D, Pourmovahed Z. The relationship between stress and addiction. Procedia Soc Behav Sci. 2013;84:1333-40.

[21] Hanpatchaiyakul K, Eriksson H, Kijsomporn J, Östlund G. Lived experience of Thai women with alcohol addiction. Asian Nurs Res. 2017;11:304-310.

[22] Borah S, Ali A. A case study of person with alcohol dependence syndrome with poor motivation. International Research Journal of Social Sciences 2016;5(3):74-79.

[23] Thurang A, Rydström J, Tops AB. Being in a safe haven and struggling against alcohol dependency. The meaning of caring for male patients in advanced addiction nursing. Issues Ment Health Nurs. 2011;32(7):401-407.

[24] Evren C, Cetin R, Durkaya M, Dalbudak E. Clinical factors associated with relapse in male alcohol dependents during six-month follow-up. Bulletin of Clinical Psychopharmacology 2010;20(1):14-22.

[25] Marini M, Schnornberger TM, Brandalise GB, Bergozza $M$, Heldt E. Quality of life determinants in patients of a psychosocial care center for alcohol and other drug users. Issues Ment Health Nurs. 2013;34(7):524-530.

[26] Dikeç G, Kutlu Y. Method for increased treatment adherence in mental disorders: adherence therapy. Journal of Psychiatric Nursing 2015;6(1):40-46.

[27] Browne KC, Wray TB, Stappenbeck CA, Krenek M, Simpson TL. Alcohol consumption, craving, and craving control efforts assessed daily in the context of readiness to change among Individuals with alcohol dependence and PTSD. J Subst Abuse Treat. 2016;61:34-41.

[28] Stapinski LA, Rapee RM, Sannibale C, Teesson M, Haber PS, Baillie AJ. The clinical and theoretical basis for integrated cognitive behavioral treatment of comorbid social anxiety and alcohol use disorders. Cognitive and Behavioral Practice 2015;22: 504-521. 
[29] Yıldırım B, Engin E, Yıldırım S. Loneliness and effective factors in alcohol and drug dependence. Journal of Psychiatric Nursing 2011;2(1):25-30.

[30] Holt-Lunstad J, Smith TB, Baker M, Harris T, Stephenson D. Loneliness and social isolation as risk factors for mortality: a meta-analytic review. Perspectives on Psychological Science 2015;10(2):227-237.

[31] Güleç G. Psikiyatrik bozukluklar ve intihar. Turkiye Klinikleri J Psychiatry-Special Topics 2016;9(3):21-25. (Turkish)
[32] Thurang AM, Palmstierna T, Tops AB. Experiences of everyday life in men with alcohol dependency - a qualitative study. Issues Ment Health Nurs. 2014;35(8):588-596

[33] Ciubara A, Burlea ŞL, Sacuiu I, Radu DA, Untu I, Chirita R. Alcohol addiction - a psychosocial perspective. Procedia Soc Behav Sci. 2015;187:536-540.

[34] Yıldırım E, Sokullu DA, Köknel Ö. Alkol bağımlıı̆̆ında içselleştirilmiş damgalanma: depresif belirtilerle ilişkisi. Psikoloji Çalışmaları Dergisi 2012;2(1):1-12. (Turkish)

How to cite this article: Bahadir Yilmaz E, Ata EE. Factors Affecting Adherence to Treatment of Inpatients with Alcohol Addiction: a Qualitative Study. Clin Exp Health Sci 2021; 11: 504-511. DOI: 10.33808/ clinexphealthsci.832339 